\title{
RELEVANSI KURIKULUM MATA KULIAH KEAHLIAN PENDIDIKAN TEKNOLOGI AGROINDUSTRI TERHADAP KOMPETENSI KEAHLIAN PENGENDALIAN MUTU UNTUK KEBUTUHAN INDUSTRI PANGAN
}

\author{
Curriculum Relevance Of Agro-industry Technology Education Core Subjects To \\ Quality Control Competencies in Food Industry \\ Septian HIImawan Jodi ${ }^{1}$, Shinta Maharani ${ }^{2}$, Yatti Sugiarti ${ }^{3}$ \\ 1,2,3 Program Studi Pendidikan Teknologi Agroindustri, \\ Fakultas Pendidikan Teknologi dan Kejuruan, Universitas Pendidikan Indonesia \\ E-mail: attisugiarti5@upi.edu
}

\begin{abstract}
ABSTRAK
Perkembangan kebutuhan kompetensi tenaga kerja pada industri harus selalu diimbangi dengan keterbaruan kurikulum perguruan tinggi. Pendidikan Teknologi Agroindustri, sebagai penyedia lulusan yang berkompeten pada bidang agoindustri, diharuskan untuk menyesuaikan kurikulum dengan kebutuhan di bidang tersebut. Penelitian ini bertujuan untuk memperoleh tingkat relevansi kurikulum Mata Kuliah Keahlian (MKK) Program Studi Pendidikan Teknologi Agroindustri (PTAG) dengan kebutuhan industri pangan pada kompetensi keahlian pengendalian mutu. Penelitian ini menggunakan metode desktriptif dengan cara analisis dokumen dan kuesioner. Studi dokumentasi dilakukan untuk mengkaji dokumen Satuan Acara Perkuliahan (SAP) dan modul praktikum Mata Kuliah Keahlian PTAG. Dokumen SKKNI Industri Pangan kompetensi keahlian pengendalian mutu digunakan dalam menyusun butir-butir pernyataan dalam kuesioner. Kuesioner ditujukan pada 7 komoditi industri pengolahan pangan yang berbeda untuk mengetahui kompetensi apa saja yang dibutuhkan industri pangan pada kompetensi keahlian pengendlian mutu. Hasil penelitian menunjukkan bahwa tingkat relevansi antara kurikulum Mata Kuliah Keahlian dengan kebutuhan kompetensi pengendalian mutu pada industri pangan adalah: $74.42 \%$ sangat relevan, $4.65 \%$ relevan, $6.97 \%$ kurang relevan, dan $13.96 \%$ tidak relevan. Hasil penelitian ini dapat menjadi rekomendasi kepada PTAG untuk mereview kembali kurikulum agar lebih sesuai dengan permintaan kebutuhan industri pangan.

Kata Kunci: relevansi kurikulum, MKK Pendidikan Teknologi Agroindustri, industri pangan, pengendalian mutu
\end{abstract}

\begin{abstract}
The development of labor competencies in the industry must always be balanced with the college curriculum renewal. Agro-industry Technology Education, as a competent graduates provider in agro-industry must constantly adjust the curriculum with the industry demands competencies. The purpose of this study was to obtain the level of curriculum relevance of Agro-industry Technology Education core subjects with the quality control (QC) competencies in food industry. The descriptive method with analizing documents and questionnaires was used in this study. Documents Study was conducted to reviewing lecture plan and core subjects practices module. National work standard competency of QC used to arrange the questionnaire statement points. The questionnaire aimed at 7 food industry with different commodity to determine the QC required competencies. The results showed that the curriculum relevance of Agro-industry Technology Education core subjects to QC competencies in food industry: $74.42 \%$ very relevant, $4.65 \%$ relevant, $6.97 \%$ less relevant, and $13.96 \%$ irrelevant. Based on the findings, it is recommended that Agro-industry Technology Education utilise the finding of the study to review their curriculum to meet food industry demands.
\end{abstract}

Keywords : curriculum relevance, Agro-industry Technology Educatin core subjects, food industry, quality control 


\section{PENDAHULUAN}

Pendidikan Teknologi Agroindustri (PTAG) merupakan salah satu program studi yang diharapkan dapat menghasilkan lulusan yang memiliki kompetensi profesional yaitu memiliki wawasan yang luas dalam bidang agroindustri, kemampuan eksplorasi, pengembangan ilmu pengetahuan, teknologi, serta berpartisipasi dalam aktivitas ilmiah komunitas profesional dalam bidang agroindustri (Tim Pengembang kurikulum Program Studi Pendidikan Teknologi Agroindustri, 2013). Relevansi kurikulum perlu dilakukan untuk menyesuaikan pendidikan dengan perkembangan ilmu pengetahuan dan teknologi serta tuntutan dunia kerja bagi siswa (Sukmadinata, 2011).

Mata Kuliah Keahlian (MKK) yang ada pada Program Studi PTAG merupakan kelompok mata kuliah yang ditujukan untuk mengembangkan kemampuan mahasiswa dalam penguasaan keahlian khususnya di bidang agroindustri. Dari aspek pengetahuan bahan agroindustri, gizi pangan, satuan operasi, rekayasa proses, pengendalian mutu, pengelolaan limbah sampai dengan aspek kewirausahaan, manajemen agroindustri dan berbagai mata kuliah yang berkaitan dengan komoditas agroindustri diberikan untuk mempersiapkan kompetensi lulusan yang dibutuhkan di dunia kerja.

Salah satu rujukan kompetensi lulusan yang menjadi dasar penyusunan kurikulum adalah Standar Kompetensi Kerja Nasional Indonesia (SKKNI). Dalam SKKNI tersebut terdapat rumusan kemampuan kerja yang mencakup aspek pengetahuan, keterampilan, keahlian serta sikap kerja yang relevan dengan pelaksanaan tugas dan syarat jabatan yang ditetapkan sesuai ketentuan peraturan perundangan yang berlaku. Selain SKKNI, rujukan kopetensi lulusan PTAG dapat berasal dari pengguna lulusan yaitu industri yang bergerak di bidang agroindustri. Bagi industri, SKKNI sebagai acuan pengembangan sumber daya manusia dan pengembangan pelatihan khusus sesuai dengan kebutuhan perusahaan.

Pada setiap industri, khususnya industri di bidang pangan membutuhkan sumber daya manusia yang dapat mengendalian terhadap kualitas produk yang diproduksi. Kompetensi pengendalian mutu sangat dibutuhkan industri agar dapat mempertahankan dan bahkan dapat meningkatkan kualitas produk yang sesuai dengan keinginan konsumen. Industri juga dapat menghemat biaya, bahan baku, waktu serta dapat mencapai target produksi yang telah ditetapkan, karena pengendalian mutu dapat cepat mengidentifikasi sistem yang tidak sesuai dengan standar yang telah ditetapkan industri tersebut (Purnomo, 2006).

Untuk menanggapi tantangan dari dunia industri, tentunya PTAG dituntut untuk selalu menyesuaikan dna mengembangkan kurikulum MKK yang ada di program studi. Penelitian ini bertujuan untuk mengetahui gambaran yang lebih jelas mengenai relevansi materi pembelajaran MKK program studi PTAG terhadap kompetensi keahlian pengendalan mutu yang dianjurkan SKKNI dan dibutuhkan dunia industri.

\section{METODE}

Penelitian ini merupakan penelitian deskriptif dengan pendekatan deskriptif kualitatif. Metode deskritif ini ialah salah satu metode penelitian yang banyak digunakan untuk menjelaskan suatu kejadian. Penelitian deskriptif adalah sebuah metode yang berusaha mendeskripsikan, menginterpretasikan sesuatu, misalnya kondisi atau hubungan yang ada, pendapat yang berkembang, proses yang sedang berlangsung, akibat atau efek yang terjadi atau tentang kecenderungan yang sedang berlangsung (Sukmadinata, 2013).

Teknik pengumpulan data yang dilakukan pada penelitian ini adalah studi dokumentasi dan kuesioner. Studi dokumentasi meliputi peninjauan Satuan Acara Perkuliahan (SAP) dan modul praktikum pada MKK PTAG. Kuesioner yang dipakai dalam menentukan relevansi kurikulum PTAG dengan dunia industri pangan berisi kompetensi keahlian pengendalian mutu sesuai dengan SKKNI Nomor; KEP. 45 / MEN / II / 2009. Validasi kuesioner ini menggunakan metode expert judgement yakni dua dosen pengampu mata kuliah pengawasan mutu PTAG.

Industri pangan yang terlibat pada penelitian ini adalah: (1) PT. Indofood Sukses MakmurBogasari Flour Mills Industri pengolahan tepung, (2) PT. Sumber Pangan Jaya Industri 
pengolahan daging (Sosis), (3) Industri Hilir Teh (Walini) PTPN VIII Industri pengolahan Teh, (4) PT. Total Samudera Sejahtera Industri pengolahan hasil laut dan perikanan (kepiting dalam kaleng), (5) PT. Berlian Cold Storage (Diamond) Industri pengolahan susu (ice cream, yoghurt), (6) PT. Heinz ABC Indonesia Industri pengolahan mie, saus, sirup dan (7) PT. Bimandiri Agro Sedaya Industri pengolahan hortikultura.

\section{HASIL DAN PEMBAHASAN}

1. Persentase Nilai Kesesuaian Kebutuhan Industri Pangan dengan Indikator Kompetensi Pengendalian Mutu SKKNI

Indikator kuesioner disusun berdasarkan kompetensi pengendalian mutu sesuai SKKNI dengan penyesuaian jenis industri pangan yang dituju. Sejumlah 43 indikator ditawarkan kepada industri pangan untuk dikaji kembali apakah indikator kompetensi yang tertulis di kuesioner sudah mencukupi kebutuhan kompetensi sumber daya manusia dalam industri tersebut. Responden yang dipilih adalah kepala pengendalian mutu atau karyawan yang bertanggung jawab terhadap pengendalian mutu produksi. Responden dapat memberikan masukan indikator kompetensi yang belum tercantum pada kuesioner. Berdasarkan hasil kajian industri-industri pangan tersebut, dihasilkan persentasi kebutuhan industri terhadap indikator kompetensi pengendalian mutu seperti yang tercantum pada Gambar 1. Sedangkan indikator-indikator yang tidak dibutuhkan oleh industri terdapat pada Tabel 1.

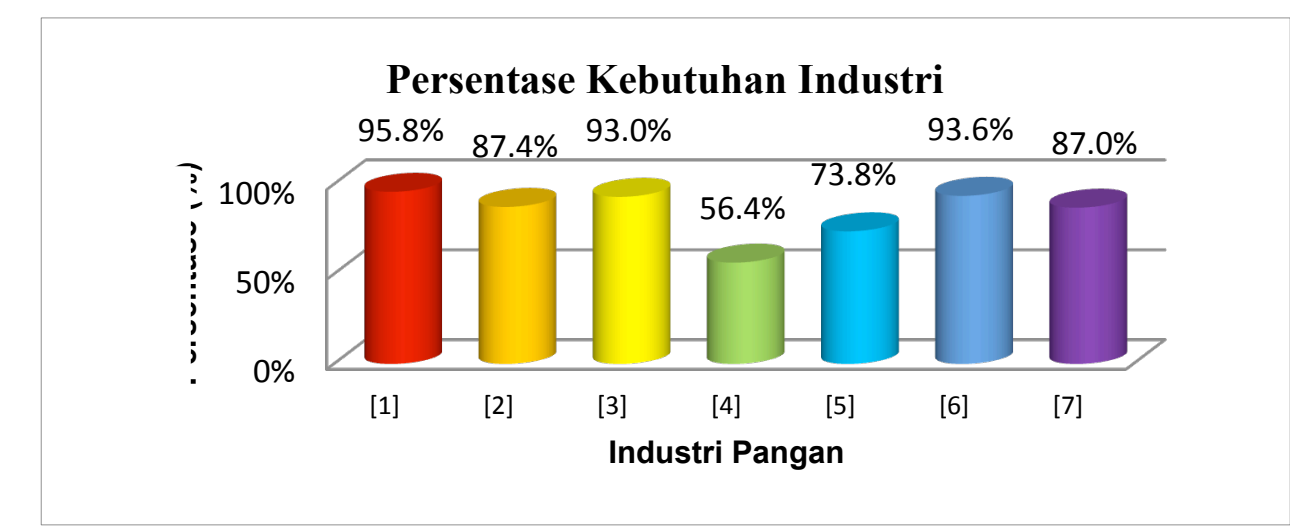

Gambar 1. Persentase kesesuaian kebutuhan materi pengendalian mutu di Industri pangan Keterangan :

(1) : : PT. Sumber Pangan Jaya (Industri Pengolahan Daging)

(2) : PT. Berlian Cold Storage (Diamond: Industri Pengolahan Susu)

(3) : PT. Total Samudera Sejahtera (Industri Pengolahan Hasil Perikanan dan Laut)

(4) : : PT. Bimandiri Agro Sedaya (Industri Pengolahan Hortikulutura)

(5) : Industri Hilir Teh PTPN VIII (Industri Pengolahan Bahan Penyegar; Teh)

(6) : : PT. Heinz Indonesia (Industri Pengolahan Mie, Saus, Minuman)

(7) : PT. Indofood Sukses Makmur Tbk. Div. Bogasari Flour Mills (Industri Pengolahan Terigu)

Tabel 1. Rangkuman indikator yang tidak dibutuhkan responden

\begin{tabular}{|c|c|c|c|c|c|c|c|c|}
\hline No. & Pernyataan & 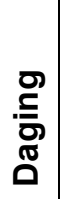 & $\stackrel{\bar{s}}{\stackrel{5}{n}}$ & $\begin{array}{l}\frac{5}{\pi} \\
\frac{\pi}{\pi} \\
\frac{5}{0} \\
0 \\
0\end{array}$ & 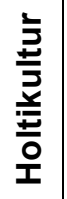 & $\stackrel{\frac{\Omega}{0}}{\vdash}$ & $\stackrel{\oplus \mathscr{\Sigma}}{\Sigma}$ & 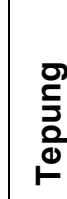 \\
\hline 1. & $\begin{array}{l}\text { Lulusan perlu memahami prinsip, teknik dan } \\
\text { metode pengambilan contoh bahan baku cair }\end{array}$ & & & & ** & ** & & \\
\hline 2. & $\begin{array}{l}\text { Peralatan sortasi dan grading bahan sesuai standal } \\
\text { yang berlaku }\end{array}$ & & & & $* *$ & & & \\
\hline
\end{tabular}




\begin{tabular}{|c|c|c|c|c|c|c|c|c|}
\hline No. & Pernyataan & 疍 & $\stackrel{\vec{\omega}}{\mathscr{m}}$ & 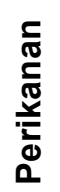 & 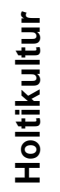 & $\stackrel{\frac{\Omega}{0}}{\vdash}$ & $\stackrel{0}{\Sigma}$ & 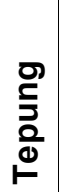 \\
\hline 3. & $\begin{array}{l}\text { Membersihkan/mengepris/menyiangi/dressing/tri } \\
m m i n g \text { dan skinning/kupas kulit (penghilangan } \\
\text { kulit) yang meliputi: } \\
\text { a. Standar mutu } \\
\text { b. Prinsip dan teknik } \\
\text { c. Peralatan yang digunakan }\end{array}$ & & ** & & & & & \\
\hline 4. & $\begin{array}{l}\text { Pengujian mutu air untuk industri pengolahan } \\
\text { pangan yang meliputi: } \\
\text { a. Identifikasi parameter mutu air } \\
\text { b. Identifikasi metode pengujian } \\
\text { c. Identifikasi peralatan dan bahan pengujian }\end{array}$ & & & & & ** & & \\
\hline 5. & $\begin{array}{l}\text { Penanganan pasca panen dan pengolahan hasil } \\
\text { pertanian/perikanan yang baik }\end{array}$ & & & & & ** & & \\
\hline 6. & $\begin{array}{l}\text { Memahami Hazard Analysis \& Critical Control } \\
\text { Point (HACCP) pada industri pangan }\end{array}$ & & & & ** & & & \\
\hline 7. & $\begin{array}{l}\text { Teknik laboratorium yang meliputi: } \\
\text { a. GLP dalam laboratorium pengujian pada industri } \\
\text { pengolahan pangan } \\
\text { b. Spesifikasi dan prinsip kerja alat laboratorium } \\
\text { c. Penanganan bahan di laboratorium } \\
\text { d. Keselamatan, Kesehatan Kerja dan lingkungan } \\
\text { Hidup (K3LH) di laboratorium }\end{array}$ & & & & ** & & & \\
\hline \multirow{5}{*}{8.} & $\begin{array}{l}\text { Teknik konversi bahan (prinsip, tujuan \& fungsi, } \\
\text { metode, faktor yang mempengaruhi, proses, dan } \\
\text { macam-macam alat proses konversi bahan) yang } \\
\text { meliputi: }\end{array}$ & & & & & & & \\
\hline & a. Pengecilan ukuran & & ** & & ** & & & \\
\hline & b. Pencampuran & & & & ** & & & \\
\hline & c. Emulsifikasi & & & & ** & ** & ** & ** \\
\hline & d. Ekstraksi/ Filtrasi/kristalisasi/ destilasi & & & ** & ** & & ** & ** \\
\hline \multirow{4}{*}{9.} & Teknik pengendalian kandungan air: & & & & & & & \\
\hline & a. Pengeringan & ** & & ** & ** & ** & & \\
\hline & b. Dehidrasi & ** & & ** & ** & ** & & ** \\
\hline & c. Rehidrasi & ** & & ** & ** & ** & & ** \\
\hline \multirow[t]{3}{*}{10.} & $\begin{array}{l}\text { Penggunaan suhu (prinsip, metode, faktor yang } \\
\text { mempengaruhi, kerusakan, dan macam-macam } \\
\text { alat) yang meliputi: }\end{array}$ & & & & & & & \\
\hline & a. Pendinginan \& pembekuan & & & & ** & ** & ** & ** \\
\hline & b. Pasteurisasi \& blansing, & ** & & & & ** & ** & ** \\
\hline 11. & $\begin{array}{l}\text { Memahami fermentasi (Prinsip dasar, } \\
\text { mikroorganisme yang berperan, kelebihan dan } \\
\text { kelemahan, faktor dan teknik pengendalian } \\
\text { fermentasi, kriteria yang baik, dan proses } \\
\text { fermentasi) }\end{array}$ & ** & & ** & ** & ** & ** & ** \\
\hline 12. & $\begin{array}{l}\text { Memahami enzimatis (Prinsip dasar, Faktor dan } \\
\text { teknik pengendalian enzimatis, kerusakan, kriteria }\end{array}$ & & & & & & & ** \\
\hline
\end{tabular}




\begin{tabular}{|c|c|c|c|c|c|c|c|c|}
\hline No. & Pernyataan & 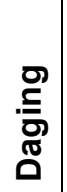 & $\stackrel{\vec{\omega}}{\omega}$ & 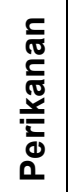 & 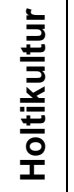 & $\stackrel{\frac{\Omega}{0}}{\circ}$ & $\stackrel{\boldsymbol{\Perp}}{\boldsymbol{\Sigma}}$ & $\begin{array}{l}\frac{0}{5} \\
\frac{0}{0} \\
\stackrel{0}{-1}\end{array}$ \\
\hline & yang baik, dan proses enzimatis) & & & & & & & \\
\hline \multirow{4}{*}{13.} & $\begin{array}{l}\text { Teknik kimiawi dalam proses pengolahan yang } \\
\text { meliputi: }\end{array}$ & & & & & & & \\
\hline & a. Sulfitasi \& karbonasi & ** & ** & ** & ** & ** & ** & ** \\
\hline & b. Netralisasi \& hidrolisis & $* *$ & ** & $* *$ & ** & ** & ** & ** \\
\hline & c. Pemurnian \& koagulasi & ** & ** & ** & ** & ** & ** & ** \\
\hline \multirow{6}{*}{14.} & $\begin{array}{l}\text { Penggunaan BTM (tujuan, jenis, fungsi masing- } \\
\text { masing BTM, mekanisme kerja masing-masing } \\
\text { BTM, keuntungan dan kerugian, penghitungan } \\
\text { dosis penggunaan masing-masing BTM) yang } \\
\text { meliputi: }\end{array}$ & & & & & & & \\
\hline & a. Pengawetan & & & & ** & ** & & \\
\hline & b. Pewarna & & & & ** & $* *$ & & \\
\hline & c. Pemanis buatan & & & & ** & ** & & \\
\hline & $\begin{array}{l}\text { d. Penyedap rasa \& aroma/penguat rasa/pengatur } \\
\text { keasaman }\end{array}$ & & & & ** & & & \\
\hline & $\begin{array}{l}\text { e. Anti kempal/antioksidan/pemutih dan pematang } \\
\text { tepung/pengemusi/pengenyal/pengeras }\end{array}$ & & ** & $* *$ & ** & ** & & \\
\hline \multirow[t]{4}{*}{15.} & $\begin{array}{l}\text { Dasar pengawetan (prinsip, mekanisme, } \\
\text { teknik/metode, faktor yang mempengaruhi, } \\
\text { kerusakan akibat proses pengawetan, kriteria } \\
\text { proses yang baik) yang meliputi: }\end{array}$ & & & & & & & \\
\hline & a. Penggulaan & & & ** & ** & ** & ** & ** \\
\hline & b. Pengasaman & & & ** & ** & ** & ** & ** \\
\hline & c. Penggaraman & & ** & ** & ** & ** & ** & ** \\
\hline \multirow{4}{*}{16.} & $\begin{array}{l}\text { Pengoperasian peralatan pengolahan yang } \\
\text { meliputi: }\end{array}$ & & & & & & & \\
\hline & a. Fungsi dan prinsip kerja & & & & & & & \\
\hline & b. Gangguan peralatan pengolahan & * & * & & & & & \\
\hline & c. Perawatan peralatan & * & * & & & & & \\
\hline 17. & $\begin{array}{l}\text { Prinsip, teknik dan metode pengambilan contoh } \\
\text { bahan hasil pengolahan berbentuk cair }\end{array}$ & ** & & ** & ** & ** & & ** \\
\hline 18. & $\begin{array}{l}\text { Prinsip, teknik dan metode pengambilan contoh } \\
\text { bahan hasil pengolahan berbentuk padat }\end{array}$ & & & & & & & \\
\hline \multirow{6}{*}{19.} & $\begin{array}{l}\text { Prinsip teknik dan metode pengujian bahan hasil } \\
\text { pertanian dan perikanan secara kimiawi (analisis } \\
\text { proksimat) yang meliputi: }\end{array}$ & & & & & & & \\
\hline & a. Kadar air & & & & ** & & & \\
\hline & b. Kadar lemak & & & & ** & * & & \\
\hline & c. Kadar abu & & & & ** & * & & \\
\hline & d. Kadar protein & & & & ** & * & & \\
\hline & e. Kadar karbohidrat & & & & ** & * & & ** \\
\hline 20. & $\begin{array}{l}\text { Prinsip, teknik dan metode pengujian bahan hasil } \\
\text { pertanian dan perikanan secara mikrobiologis } \\
\text { yang meliputi: } \\
\text { a. Penyiapan media }\end{array}$ & & & & ** & * & & \\
\hline
\end{tabular}




\begin{tabular}{|c|c|c|c|c|c|c|c|c|}
\hline No. & Pernyataan & 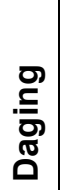 & 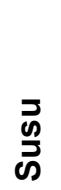 & $\begin{array}{l}\frac{c}{D} \\
\frac{1}{0} \\
\frac{1}{0} \\
\frac{\mathbf{L}}{0} \\
0\end{array}$ & 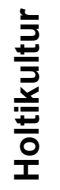 & ऽ & $\stackrel{\underline{0}}{\Sigma}$ & 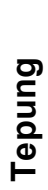 \\
\hline & $\begin{array}{l}\text { b. Pewarnaan } \\
\text { c. Pengenceran } \\
\text { d. Pembiakan }\end{array}$ & & & & & & & \\
\hline 21. & $\begin{array}{l}\text { Prinsip, teknik dan metode pengujian bahan hasil } \\
\text { pertanian dan perikanan secara spektrofotometri }\end{array}$ & & * & & $* *$ & & & ** \\
\hline 22. & $\begin{array}{l}\text { Prinsip, teknik dan metode pengujian bahan hasil } \\
\text { pertanian dan perikanan secara potensiometri }\end{array}$ & & & & ** & & & ** \\
\hline 23. & $\begin{array}{l}\text { Prinsip, teknik dan metode pengujian bahan hasil } \\
\text { pertanian dan perikanan secara kromatografi }\end{array}$ & & * & & ** & & & ** \\
\hline 24. & $\begin{array}{l}\text { Prinsip, teknik dan metode pengujian kandungan } \\
\text { mineral pada bahan hasil pertanian dan } \\
\text { perikanan }\end{array}$ & & * & & ** & & & \\
\hline 25. & $\begin{array}{l}\text { Prinsip, teknik dan metode pengujian kandungan } \\
\text { vitamin pada bahan hasil pertanian dan perikanan }\end{array}$ & & * & & & & & ** \\
\hline 26. & $\begin{array}{l}\text { Prinsip, teknik dan metode pengujian adanya } \\
\text { bahan berbahaya pada bahan hasil pertanian dan } \\
\text { perikanan }\end{array}$ & & & & ** & & & \\
\hline 27. & $\begin{array}{l}\text { Prinsip, teknik dan metode pengujian adanya } \\
\text { kandungan alkohol }\end{array}$ & & & & ** & & & ** \\
\hline 28. & $\begin{array}{l}\text { Uji organoleptik yang meliputi: } \\
\text { a. Prinsip, teknik dan metode pengujian ambang } \\
\text { rangsangan (threshold) } \\
\text { b. Prinsip, teknik dan metode uji kesukaan dan } \\
\text { mutu hedonik } \\
\text { c. Prinsip, teknik dan metode uji pembeda }\end{array}$ & & & & ** & & & \\
\hline
\end{tabular}

Ket :

* Industri yang dijadikan responden menggunakan jasa dari divisi lain dan jasa dari pihak lain.

** Industri yang dijadikan responden tidak menggunakan teknologi tersebut pada proses pengendalian mutu produksinya.

Berdasarkan Gambar 1 dan Tabel 1, terlihat bahwa tidak semua indikator kompetensi pengendalian mutu menurut SKKNI harus dipunyai oleh calon karyawan yang akan bekerja di bagian pengendalian mutu. Beberapa indikator dapat dilakukan oleh divisi lain selain bagian pengendalian mutu. Sebagai contoh, PT. Berlian Cold Storage (Diamond: Industri pengolahan susu), PT. Sumber Pangan Jaya (Industri pengolahan daging) mempercayakan perihal perawatan peralatan produksi kepada divisi engineering. Apabila industri yang bersangkutan tidak memiliki peralatan pengujian, maka pengujian dapat dilakukan oleh perusahan/jasa pengujian yang lain. Untuk kategori alasan dikerjakan divisi lain dan jasa dari pihak lain didapatkan persentase rataan sebesar 9,01\%.

Selain dikerjakan oleh pihak lain, beberapa industri memang tidak membutuhkan indikator tersebut. Alasan industri tidak menggunakan teknik tersebut dalam proses produksinya memiliki persentase rataan sebesar 90,99\%. Industri Pengolahan Hortikultura (PT. Bimandiri Agro Sedaya) ini mempunyai persentase kebutuhan materi tentang pengendalian mutu yang dibutuhkan sebesar 56,38\% dengan kategori cukup relevan, ada $43,62 \%$ indikator yang dinyatakan tidak dibutuhkan industri ini. PT. Bimandiri Agro Sedaya adalah perusahaan yang bergerak di bidang agrotrading. Penanganan paska panen yang dilakukan dimulai dari penerimaan sayuran segar dari petani, pemilihan berdasarkan standar kualitas yang diinginkan sampai proses pengemasan sesuai dengan jenis komoditi 
yang dihasilkan. Kategori persentase yang belum terlalu tinggi dikarenakan bahan baku yang diperoleh masih dalam keadaan segar tanpa melakukan proses pengolahan produk. Industri ini belum melakukan analisis laboratorium dalam skala besar jadi masih belum membutuhkan semua indikator kompetensi pengendalian mutu sesuai dengan SKKNI.

Responden menambahkan bahwa pada dasarnya sumber daya manusia yang bekerja sebagai pengendali mutu suatu industri lebih baik jika memiliki semua indikator kompetensi yang sudah dianjurkan oleh SKKNI. Menurut Tuloli (2006), SDM yang dibutuhkan oleh dunia usaha dan industri adalah tenaga kerja yang dapat menghadapi tantangan perubahan teknologi, karena perkembangan teknologi industri menuntut peningkatan penguasaan pengetahuan, kemampuan dan keterampilan sumber daya manusianya.

\title{
2. Rata-rata nilai relevansi Mata Kuliah Keahlian dengan Industri
}

Rata-rata nilai relevansi MKK program studi PTAG dengan kebutuhan industri didapatkan dari kajian data antara indikator keahlian pengendalian mutu yang dibutuhkan dunia industri dengan dokumen SAP dan modul praktikum PTAG. Tingkat relevansi antara Mata Kuliah Keahlian Pendidikan Teknologi Agroindustri dengan kebutuhan industri pangan dapat dilihat pada Gambar 2.

\section{Tingkat Relevansi}

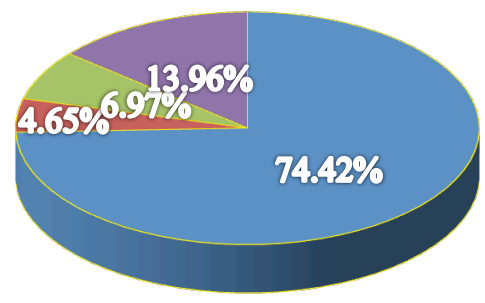

\author{
- Sangat Relevan \\ nelevan \\ Kurang Relevan \\ - Tidak Relevan
}

Gambar 2. Grafik tingkat relevansi antara Mata Kuliah Keahlian Pendidikan Teknologi Agroindustri dengan kebutuhan Industri Pangan

Berdasarkan grafik tingkat relevansi, kriteria relevansi yang sangat relevan sebesar $74,42 \%$, kriteria sangat relevan ini didapat sesuai dengan berdasarkan konversi persentase menurut Sugiyono (2014). Kriteria sangat relevan ini didapat karena cakupan pada poin butir instrumen kuesioner kebutuhan pengendalian mutu terpenuhi dengan SAP dan modul praktikum Mata Kuliah Keahlian Pendidikan Teknologi Agroindustri. Kriteria relevansi yang relevan terdapat $4,65 \%$, karena cakupan pada poin butir instrumen kuesioner kebutuhan di kompetensi pengendalian mutu terpenuhi tetapi masih ada beberapa materi yang belum termuat pada SAP dan modul praktikum Mata Kuliah Keahlian Pendidikan Teknologi Agroindustri.

Kebutuhan industri yang relevan dengan MKK program studi adalah:

1) Kompetensi mengenal karakteristik bahan baku sesuai dengan pengetahuan penunjang memahami berbagai jenis dan karakteristik komoditas/produk;

2) Kompetensi memahami dasar-dasar proses pengolahan produksi, pengendalian, pengujian, pengemasan dan penyimpanan dengan baik;

3) Kompetensi memahami dasar-dasar proses analisis dan pengujian produk;

4) Fungsi dan prinsip kerja peralatan;

5) Memahami GMP, HACCP, ISO pada dunia industri pangan;

6) Menghitung data secara statistik.

Kriteria relevansi yang dikatakan kurang relevan sebesar $6,97 \%$, terdapat 
beberapa cakupan pada poin butir instrumen kuesioner kebutuhan kompetensi pengendalian mutu kurang terpenuhi pada SAP dan modul praktikum Mata Kuliah Keahlian Pendidikan Teknologi Agroindustri. Hasil tingkat relevansi yang dikatakan tidak relevan sebesar $13,96 \%$, kriteria tidak relevan karena cakupan pada poin butir instrumen kuesioner kebutuhan di pengendalian mutu tidak terpenuhi pada SAP dan modul praktikum Mata Kuliah Keahlian Pendidikan Teknologi Agroindustri.

Berdasarkan kajian tingkat relevansi, didapatkan beberapa indikator kompetensi pengendalian mutu yang belum terdapat pada satuan acara perkuliahan PTAG, diantaranya:

1) Klasifikasi komoditas berdasarkan $\mathrm{FAO}$, jaminan produk halal;

2) Prinsip, teknik dan metode pengujian bahan hasil pertanian secara potensiometri, kromatografi;

3) Pengujian kandungan bahan kimia tambahan, vitamin, kandungan alkohol;

4) Prinsip, teknik dan metode pengambilan contoh bahan hasil pengolahan cair dan padat.

Adanya hasil penelitian tentang relevansi kebutuhan dunia industri dengan MKK program studi PTAG ini dapat menjadi tantangan bagi PTAG untuk selalu memperbaharui kurikulum yang sudah ada. Menurut Danim (2002), desain kurikulum dipandu oleh kebutuhan eksternal (pasar) dan sejalan dengan tuntutan dunia usaha. Hal tersebut juga sesuai dengan pendapat yang diungkapkan oleh Arifin Z., (2011) bahwa kurikulum harus bersifat dinamis. Artinya, kurikulum selalu mengalami perubahan dan teknologi, tingkat kecerdasan peserta didik, kultur, sistem nilai, serta kebutuhan masyarakat.

\section{KESIMPULAN}

Dari seluruh materi yang terdapat pada SAP dan modul praktikum Mata Kuliah Keahlian Pendidikan Teknologi Agroindustri, dapat diketahui hasil penilaian relevansinya dengan kebutuhan industri pangan adalah: $74.42 \%$ sangat relevan, $4.65 \%$ relevan, $6.97 \%$ kurang relevan, dan $13.96 \%$ tidak relevan.

\section{DAFTAR PUSTAKA}

Arifin, Z. (2011). Konsep dan model pengembangan kurikulum. Bandung: PT. Remaja Rosdakarya Offset.

Danim, S. (2002). Menjadi komunitas pembelajar. Jakarta: Bumi Aksara.

Purnomo, Edy. (2006). Pengaruh quality control terhadap tingkat kerusakan produk pada PT. Filma Utama Soap Surabaya. Jurnal IImu-ilmu Sosial. 6 (2), hlm. 116-121.

Sugiyono. (2014). Metode penelitian pendidikan pendekatan kuantitatif, kualitatif, dan R\&D. Bandung: Alfabeta.

Sukmadinata, N.S. (2011). Pengembangan kurikulum: Teori dan Praktek. Bandung: Remaja Rosdakarya.

Sukmadinata, N.S. (2013). Metode Penelitian Pendidikan. Bandung: Remaja Rosdakarya.

Tim Pengembang Kurikulum Pendidikan Teknologi Agroindustri. (2013). Kurikulum program sarjana pendidikan. [Online]. Diakses dari: http://agroindustri.upi.edu/?page_id=179.

Tuloli, N. (2006). Issu Strategis Pengembangan Pendidikan Teknologi Kejuruan. APTEKINDO. 